\title{
Penilaian Guru terhadap Pelaksanaan Model-Model Tilawah al-Quran Program j-QAF
}

\author{
Teachers Evaluation on the Implementation of j-QAF Quranic \\ Recitation Models
}

\author{
AB. HALIM TAMURI*, AHMAD MUNAWAR ISMAIL, AMAL HAYATI MD. NOOR \& \\ MOHD IZZUDDIN MOHD PISOL ${ }^{1}$
}

\begin{abstract}
This survey aimed to identify the level of implementation in the $j$-QAF Quranic Recitation program (6 Months Model of Khatam al-Quran, Tasmik Model, Asuhan Tilawah al-Quran and al-Quran Literacy Camp). This study used a quantitative approach (questionnaire) to gather information from 240 Islamic Education and jQAF teachers from 24 primary schools in Kuala Selangor, Klang and Hulu Langat district in Selangor. Data were analyzed descriptively using frequency, percentage and mean. Pearson's test was also conducted to examine the relationships between the implementation of these models. Generally, from the data analysis, it was found that the level of implementation in the models of Quranic Recitation j-QAF were high. The study found that there were siginificant relationships between the teachers' evaluation on the four models of Quranic Recitation $j-Q A F$.
\end{abstract}

Keywords: j-Qaf, Quranic teaching, Quranic recitation, religious education

Program j-QAF yang diperkenalkan pada tahun 2005 merupakan salah satu usaha penting ke arah memartabatkan al-Quran dalam kalangan pelajar-pelajar sekolah seluruh Malaysia. Salah satu objektif utama program yang mahu dicapai dalam bidang tilawah al-Quran adalah ingin melahirkan pelajar yang bukan sahaja menguasai bacaan al-Quran dengan baik malah khatam al-Quran sebelum menjejakkan kaki ke sekolah menengah dengan mengenengahkan beberapa model yang terdapat dalam program tersebut. Secara ringkasnya, program j-QAF merupakan usaha untuk memperkasakan pelaksanaan Pendidikan Islam di sekolah rendah melalui penekanan penguasaan dalam bidang jawi, al-Quran, bahasa Arab dan fardu ain (Ghazali 2007). Usaha ini seiring dengan matlamat Pendidikan Islam yang berusaha melahirkan Muslim berilmu, beriman, berketerampilan, beramal soleh, beradab dan berakhlak mulia berdasarkan al-Quran dan al-Sunnah sebagai hamba dan khalifah Allah yang bertakwa serta menyumbang kepada tamadun bangsa dan negara.

\section{Latar Belakang Kajian}

Secara umumnya, terdapat lima model pengajaran yang diperkenalkan dalam program j-QAF iaitu Model Kelas Pemulihan Jawi, Model Khatam al-Quran, Model Tasmik, Model Bahasa Arab Komunikasi dan Model Kem Bestari Solat (Zaidi et al. 2008). Bagi mencapai matlamat penguasaan bacaan al-Quran, terdapat model sukatan lanjutan dan modul tilawah al-Quran program j-QAF yang diperkenalkan iaitu Model 6 bulan Khatam al-Quran, Model Tasmik,

${ }^{1}$ Ab. Halim Tamuri*(Corresponding author), Ph.D., Assoc. Prof. at Dept. of Educational Leadership and Policy, Faculty of Education Universiti Kebangsaan Malaysia, 43600 BANGI Selangor, Malaysia, Email: tamuri67@gmail.com; Ahmad Munawar Ismail, Ph.D., Senior Lecturer at the Dept. of Theology and Philosophy, Faculty of Islamic Studies, Universiti Kebangsaan Malaysia, 43600 BANGI Selangor, Malaysia, Email: munawar@ukm.my; Amal Hayati Md Noor. M.A., Email: siraj_iman@yahoo.com; Mohd Izzuddin Mohd Pisol B.A., Email: mpmizzuddin@gmail.com. 
Asuhan Tilawah al-Quran, dan Kem Literasi al-Quran. Keempat-empat model ini menekankan aspek bacaan al-Quran melalui pendekatan kaedah Talaqqi dan Musyafahah sebagai medium pengajaran. Kaedah Talaqqi dan Musyafahah adalah satu proses pengajaran dan pembelajaran secara bersemuka antara guru dengan pelajar bagi mendengar. Untuk mencapai hasrat membimbing pelajar sehingga khatam, pendekatan yang dianjurkan ialah menerusi kaedah talaqqi dan musyafahah iaitu kaedah pembelajaran secara bersemuka dengan guru bagi mendengar, membetulkan kesalahan dan menyebut semula dengan baik dan lancar. Malah, sebelum wujudnya program j-QAF, kaedah talaqqi dan musyafahah ini telah digunapakai dalam proses pengajaran dan pembelajaran Asuhan Tilawah al-Quran kurikulum KBSR. (Kementerian Pelajaran Malaysia 2005; Kementerian Pelajaran Malaysia 2008).

Walaupun al-Quran diajar dalam sukatan asuhan Tilawah al-Quran dalam kurikulum Pendidikan Islam sebelum diperkenalkan program j-QAF, namun ia hanya menjurus kepada kebolehan membaca sahaja. Manakala aspek khatam tidak ditekankan di sekolah tetapi menyerahkannya kepada masyarakat (Kementerian Pendidikan Malaysia 2005). Bagi mencapai matlamat ini, ia memerlukan bimbingan yang berterusan daripada beberapa orang guru yang mengajar berdasarkan nisbah pelajar di sesebuah kelas dan sekolah. Guru j-QAF akan membantu dan bersama-sama Guru Pendidikan Islam mengajar tilawah al-Quran dalam kelas yang sama. Ini bermakna lebih daripada seorang guru yang mengajar tilawah al-Quran dalam sesuatu masa berbanding pelaksanaan sebelum ini hanya guru pendidikan Islam seorang sahaja yang akan mengajar tilawah al-Quran kepada 30 hingga 40 orang pelajar dalam sesebuah kelas. Berdasarkan hasil kajian Mohd Aderi \& Rohani (2009) yang memfokuskan tentang kelemahan penguasaan kemahiran membaca al-Quran di kalangan pelajar walaupun mereka telah melalui enam tahun pembelajaran di sekolah rendah. Walaupun pelajar telah khatam Al-Quran, ia bukan satu jaminan pelajar menguasai al-Quran sebagaimana hasil kajian sebelum ini oleh Mohd Aderi (2004) tentang celik al-Quran kalangan pelajar tingkatan satu yang menunjukkan bahawa walaupun 63\% daripada responden telah khatam al-Quran tetapi tahap bacaan keseluruhan responden adalah pada tahap sederhana dan lemah.

Menurut Mohd Azmir dan Mohd Azrani (2009), tempoh enam bulan pertama yang diperuntukkan untuk pelajar tahun satu menguasai bacaan buku Iqra 1 hingga 6 adalah tidak mencukupi. Masalah ini disebabkan pada awal sesi persekolahan, semua pelajar tahun satu akan mengikuti Program Transisi Guru Penyayang selama dua minggu dan pelbagai aktiviti sekolah termasuk sukan tahunan dan sebagainya. Selain itu, pelajar juga terpaksa mengikut sukatan bacaan al-Quran walaupun tidak menguasai bacaan. Walaupun pelajar mengikuti kaedah Baca Ikut Guru (BIG), namun kualiti bacaan pelajar sangat rendah masih ada yang tidak mampu mengenal huruf hijaiyyah dengan baik. Keadaan ini dibimbangi dapat menjejaskan kualiti bacaan pelajar walaupun mereka telah khatam tetapi masih tidak mampu menguasai bacaan alQuran dengan baik. Mohd Azmir dan Mohd Azrani (2009) turut menyatakan semenjak program j-QAF diperkenalkan, terdapat ramai ibu bapa yang tidak menghantar anak-anak mereka untuk menghadiri kelas mengaji di luar. Situasi ini memberi kesan yang kurang baik kepada program j-QAF. Ini adalah kerana kelas mengaji di luar sebenarnya membantu pelajar menguasai kemahiran membaca al-Quran dengan lebih baik dan cepat. Sekiranya pelajar bergantung sepenuhnya kepada guru-guru j-QAF, dibimbangi pelajar akan lambat menguasai dan khatam al-Quran atau lebih teruk lagi berlaku keciciran dalam penguasaan bacaan al-Quran.

Kekurangan bahan bantu mengajar (BBM) terutamanya buku Iqra' dan al-Quran turut menyukarkan pelaksanaan Pengajaran dan Pembelajaran tilawah al-Quran. Ketidakcukupan ini memaksa pelajar berkongsi dengan pelajar lain dan menjejaskan penguasaan al-Quran. Berdasarkan isu-isu yang dikemukakan menunjukkan masih terdapat kelemahan dan kekurangan yang perlu ditangani bagi mengatasi kelemahan dalam penguasaan bacaan alQuran kalangan pelajar agar tidak terus berlanjutan walaupun setelah dilaksanakan program jQAF. Sehubungan itu, kajian ini dijalankan bagi menilai pelaksanaan pengajaran Tilawah alQuran program j-QAF berdasarkan guru-guru Pendidikan Islam dan guru j-QAF. Disamping itu, ia juga mengenalpasti kekuatan dan kelemahan pelaksanaan pengajaran Tilawah al-Quran setelah hampir tujuh tahun program ini dilaksanakan. 


\section{Metodologi Kajian}

Objektif kajian ini ialah untuk melihat tahap pelaksanaan Model Tilawah al-Quran yang merangkumi model-model: Model 6 bulan Khatam al-Quran, Model Tasmik, Asuhan Tilawah alQuran, dan Kem Literasi al-Quran. Kajian ini memberi tumpuan kepada penilaian guru-guru pendidikan Islam dan j-QAF terhadap model-model yang dilaksanakan di sekolah-sekolah rendah. Kajian yang dijalankan ini berbentuk kajian tinjauan (exploratory research) yang menggunakan pendekatan kuantitatif. Data dikumpulkan dari 24 buah sekolah kebangsaan melibatkan 3 zon iaitu zon utara (Kuala Selangor), zon tengah (Klang), zon selatan (Hulu Langat) di negeri Selangor yang melibatkan seramai 240 orang guru. Berdasarkan kaedah persampelan rawak berkelompok, penyelidik telah menjalankan kajian ke atas 240 orang responden iaitu 20\% daripada sejumlah 1198 populasi guru pendidikan Islam yang terlibat dalam pelaksanaan j-QAF dan ini melebihi jumlah minima yang ditetapkan oleh Neuman (2003). Kajian ini menggunakan satu set soal selidik yang dibahagikan kepada tiga bahagian iaitu demografi responden, Asuhan Tilawah al-Quran dan pengunaan bahan bantu pengajaran. Guruguru terpilih diminta menjawab borong soal selidik pelaksanaan Asuhan Tilawah al-Quran program j-QAF yang menggunakan lima skala Likert. Hasil ujian rintis, nilai Pekali Kebolehpercayaan Alpha Cronbach instrumen ini juga adalah tinggi seperti berikut:

Jadual 1: Tahap Kebolehpercayaan Alpha Cronbach Instrumen Kajian

\begin{tabular}{lcc}
\hline Aspek & Bil. Item & Nilai Alpha Cronbach \\
\hline Tahap Model 6 Bulan Khatam al-Quran & 26 & 0.897 \\
Tahap Model Tasmik & 22 & 0.940 \\
Tahap Asuhan Tilawah al-Quran & 13 & 0.934 \\
Tahap Kem Literasi al-Quran & 27 & 0.961 \\
\hline
\end{tabular}

Instrumen ini juga telah disemak oleh tiga pakar dalam bidang pendidikan Islam bagi menentukan tahap keesahan kandungan. Data yang dikumpulkan dianalisis secara diskriptif dengan melihat taburan kekerapan, min dan sisihan piawai serta analisis juga dengan korelasi Pearson untuk melihat hubungan penilaian guru-guru terhadap model Tilawah al-Quran j-QAF.

\section{Profil Sampel Kajian}

Sampel kajian melibatkan 240 orang guru Pendidikan Islam yang dipilih secara rawak sebagai responden dalam kajian ini. Berikut adalah latar belakang sampel kajian:

Jadual 2: Profil Responden Kajian

\begin{tabular}{llll}
\hline Kategori & Profil & Kekerapan & Peratus \% \\
\hline Jantina & Lelaki & 42 & 17.5 \\
& Perempuan & 198 & 82.5 \\
Pengalaman mengajar Pendidikan Islam & $<1$ tahun & 9 & 3.8 \\
& $1-3$ tahun & 47 & 19.6 \\
& $4-6$ tahun & 64 & 26.7 \\
& $7-9$ tahun & 38 & 15.8 \\
& 10 tahun dan lebih & 82 & 34.2
\end{tabular}




$\begin{array}{llll}\text { Kelayakan akademik tertinggi } & \text { SPM } & 26 & 10.8 \\ & \text { Sijil/STPM/Diploma } & 55 & 22.9 \\ & \text { Ijazah Sarjana Muda } & 143 & 59.6 \\ & \text { Sarjana } & 16 & 6.7 \\ \text { Kelayakan ikhtisas } & & \\ & \text { Tiada } & 9 & 3.8 \\ & \text { Diploma Pendidikan } & 69 & 28.8 \\ & \text { KPLI } & 115 & 47.9 \\ \text { Sijil Perguruan } & 47 & 19.6 \\ \text { Umur } & & \\ & <\text { daripada } 25 \text { tahun } & 9 & 3.8 \\ & 25-35 \text { tahun } & 125 & 52.1 \\ & 36-45 \text { tahun } & 89 & 37.1 \\ & >\text { daripada } 45 \text { tahun } & 17 & 7.1\end{array}$

Jadual 2 menunjukkan profil demografi guru Pendidikan Islam sekitar daerah Bangi dan Kajang yang terlibat dalam kajian ini. Dari segi komposisi jantina, data menunjukkan 42 orang (17.5\%) adalah lelaki dan 198 orang (82.5\%) adalah perempuan. Jumlah responden perempuan adalah melebihi daripada jumlah responden lelaki seramai 156 orang. Berdasarkan tempoh pengalaman mengajar Pendidikan Islam menunjukkan bahawa guru yang mengajar Pendidikan Islam kurang daripada 1 tahun adalah seramai 9 orang (3.8\%), mengajar 1 hingga 3 tahun adalah 47 orang (19.6\%), mengajar 4 hingga 6 tahun adalah 64 orang (26.7\%), 7 hingga 9 tahun adalah sebanyak 38 orang (15.8\%) dan mengajar melebihi 10 tahun adalah 82 orang (34.2\%).

Berdasarkan kelayakan akademik yang tertinggi, data menunjukkan bahawa guru yang memiliki SPM adalah sebanyak 26 orang (10.8\%), berkelayakan Sijil/ STPM/ Diploma adalah 55 orang (22.9\%), berkelayakan Ijazah Sarjana Muda adalah seramai 143 orang (59.6\%) dan guru yang memiliki ijazah Sarjana adalah seramai 16 orang (6.7\%). Dilihat daripada kelayakan ikhtisas, data menunjukkan 9 orang (3.8\%) adalah guru yang tiada kelayakan ikhtisas, seramai 69 orang (28.8\%) memiliki Diploma Perguruan, 115 orang guru (47.9\%) memiliki sijil Kursus Perguruan Lepasan Ijazah (KPLI) dan 47 orang (19.6\%) mempunyai Sijil Perguruan. Bagi kategori umur, data menunjukkan guru yang berumur kurang daripada 25 tahun adalah 9 orang (3.8\%), berumur 25 hingga 35 tahun 125 orang (52.1\%), berumur 36 hingga 45 tahun adalah 89 orang (37.1\%), manakala guru yang berumur lebih daripada 45 tahun adalah sebanyak 17 orang $(7.1 \%)$.

\section{Dapatan Deskriptif}

Analisis deskriptif digunakan bagi menerangkan dapatan kajian berdasarkan jawapan responden terhadap item-item yang dikemukakan dalam soal selidik. Bagi tujuan interpretasi data deskriptif, dapatan kajian dianalisis berpandukan kepada jadual interpretasi skor min Norasmah (2002) dan Azhar (2006) seperti yang dinyatakan dalam Jadual 3 berikut:

Jadual 3: Interpretasi Min

\begin{tabular}{cc}
\hline Skor Min & Interpretasi \\
\hline $4.01-5.00$ & Tinggi \\
$3.01-4.00$ & Sederhana Tinggi \\
$2.01-3.00$ & Sederhana Rendah \\
$1.01-2.00$ & Rendah \\
\hline
\end{tabular}

Norasmah (2002) dan Azhar (2006) 


\section{a. Pelaksanaan Pengajaran Tilawah al-Quran Program j-QAF (Model 6 Bulan Khatam al-Quran)}

Model 6 Bulan Khatam al-Quran adalah merujuk kepada salah satu model yang diperkenalkan dalam pengajaran tilawah al-Quran program j-QAF. Berikut adalah penilaian guru-guru terhadap pelaksanaan Model 6 Bulan Khatam Al-Quran.

Jadual 4: Penilaian Guru Terhadap Pelaksanaan Model 6 Bulan Khatam al-Quran

\begin{tabular}{|c|c|c|c|c|c|c|c|c|c|}
\hline \multirow{2}{*}{$z$} & \multirow{2}{*}{ Item } & \multicolumn{5}{|c|}{ Kekerapan \& Peratus(N=240) } & \multirow{2}{*}{ Min } & \multirow{2}{*}{ SP } & \multirow{2}{*}{ INT } \\
\hline & & STS & TS & KS & $\mathbf{S}$ & SS & & & \\
\hline$\underset{\varpi}{\varpi}$ & $\begin{array}{l}\text { Memahami dengan jelas } \\
\text { objektif Model } 6 \text { Bulan } \\
\text { Khatam al-Quran. }\end{array}$ & - & $\begin{array}{r}5 \\
(2.1 \%)\end{array}$ & $\begin{array}{r}11 \\
(4.6 \%)\end{array}$ & $\begin{array}{r}142 \\
(59.2 \%)\end{array}$ & $\begin{array}{r}82 \\
(34.2 \%)\end{array}$ & 4.25 & 0.639 & $\mathrm{~T}$ \\
\hline$\stackrel{\square}{N}$ & $\begin{array}{l}\text { Melaksanakan Model } 6 \\
\text { Bulan Khatam al-Quran } \\
\text { pada enam bulan pertama } \\
\text { (Jan hingga Jun). }\end{array}$ & $\begin{array}{r}3 \\
(1.3 \%)\end{array}$ & $\begin{array}{r}5 \\
(2.1 \%)\end{array}$ & $\begin{array}{r}10 \\
(4.2 \%)\end{array}$ & $\begin{array}{r}126 \\
(52.5 \%)\end{array}$ & $\begin{array}{r}96 \\
(40.0 \%)\end{array}$ & 4.28 & 0.750 & $\mathrm{~T}$ \\
\hline$\stackrel{\varpi \omega}{\omega}$ & $\begin{array}{l}\text { Melaksanakan pengajaran } \\
\text { berdasarkan objektif } \\
\text { pengajaran. }\end{array}$ & - & $\begin{array}{r}1 \\
(0.4 \%)\end{array}$ & $\begin{array}{r}10 \\
(4.2 \%)\end{array}$ & $\begin{array}{r}146 \\
(60.8 \%)\end{array}$ & $\begin{array}{r}83 \\
(34.6 \%)\end{array}$ & 4.30 & 0.564 & $\mathrm{~T}$ \\
\hline$\stackrel{\varpi}{\phi}$ & $\begin{array}{l}\text { Memastikan di akhir P\&P, } \\
\text { pelajar dapat menguasai } \\
\text { objektif pengajaran dengan } \\
\text { baik. }\end{array}$ & - & - & $\begin{array}{r}6 \\
(2.5 \%)\end{array}$ & $\begin{array}{r}148 \\
(61.7 \%)\end{array}$ & $\begin{array}{r}86 \\
(35.8 \%)\end{array}$ & 4.33 & 0.523 & $\mathrm{~T}$ \\
\hline$\stackrel{\mathscr{\sigma}}{\sim}$ & $\begin{array}{l}\text { Melaksanakannya } \\
\text { berdasarkan waktu yang } \\
\text { diperuntukkan. }\end{array}$ & - & - & $\begin{array}{r}8 \\
(3.3 \%)\end{array}$ & $\begin{array}{r}135 \\
(56.3 \%)\end{array}$ & $\begin{array}{r}97 \\
(40.4 \%)\end{array}$ & 4.37 & 0.549 & $\mathrm{~T}$ \\
\hline ஜூ & $\begin{array}{l}\text { Melakukan ujian ringkas } \\
\text { sebelum melaksanakan } \\
\text { pengajaran untuk tujuan } \\
\text { diagnostik. }\end{array}$ & - & $\begin{array}{r}5 \\
(2.1 \%)\end{array}$ & $\begin{array}{r}33 \\
(13.8 \%)\end{array}$ & $\begin{array}{r}163 \\
(67.9 \%)\end{array}$ & $\begin{array}{r}39 \\
(16.3 \%)\end{array}$ & 3.98 & 0.620 & ST \\
\hline 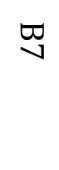 & $\begin{array}{l}\text { Membahagikan pelajar } \\
\text { kepada beberapa } \\
\text { kumpulan mengikut tahap } \\
\text { kebolehan pelajar. }\end{array}$ & $\begin{array}{r}1 \\
(0.4 \%)\end{array}$ & $\begin{array}{r}4 \\
(1.7 \%)\end{array}$ & $\begin{array}{r}14 \\
(5.8 \%)\end{array}$ & $\begin{array}{r}148 \\
(61.7 \%)\end{array}$ & $\begin{array}{r}73 \\
(30.4 \%)\end{array}$ & 4.20 & 0.655 & $\mathrm{~T}$ \\
\hline$\stackrel{\infty}{\infty}$ & $\begin{array}{l}\text { Melaksanakan pengajaran } \\
\text { di tempat yang sesuai } \\
\text { dengan untuk pengajaran } \\
\text { tilawah al-Quran. }\end{array}$ & - & - & $\begin{array}{r}8 \\
(3.3 \%)\end{array}$ & $\begin{array}{r}143 \\
(59.6 \%)\end{array}$ & $\begin{array}{r}89 \\
(37.1 \%)\end{array}$ & 4.34 & 0.540 & $\mathrm{~T}$ \\
\hline డ్ర & $\begin{array}{l}\text { Menggunakan kaedah } \\
\text { talaqqi dan musyafahah. }\end{array}$ & - & $\begin{array}{r}1 \\
(0.4 \%)\end{array}$ & $\begin{array}{r}6 \\
(2.5 \%)\end{array}$ & $\begin{array}{r}109 \\
(45.4 \%)\end{array}$ & $\begin{array}{r}124 \\
(51.7 \%)\end{array}$ & 4.48 & 0.571 & $\mathrm{~T}$ \\
\hline$\stackrel{\varpi 0}{\Xi}$ & $\begin{array}{l}\text { Menggunakan kaedah } \\
\text { selain kaedah talaqqi dan } \\
\text { musyafahah. }\end{array}$ & $\begin{array}{r}4 \\
(1.7 \%)\end{array}$ & $\begin{array}{r}5 \\
(2.1 \%)\end{array}$ & $\begin{array}{r}33 \\
(13.8 \%)\end{array}$ & $\begin{array}{r}139 \\
(57.9 \%)\end{array}$ & $\begin{array}{r}59 \\
(24.6 \%)\end{array}$ & 4.02 & 0.787 & $\mathrm{~T}$ \\
\hline
\end{tabular}




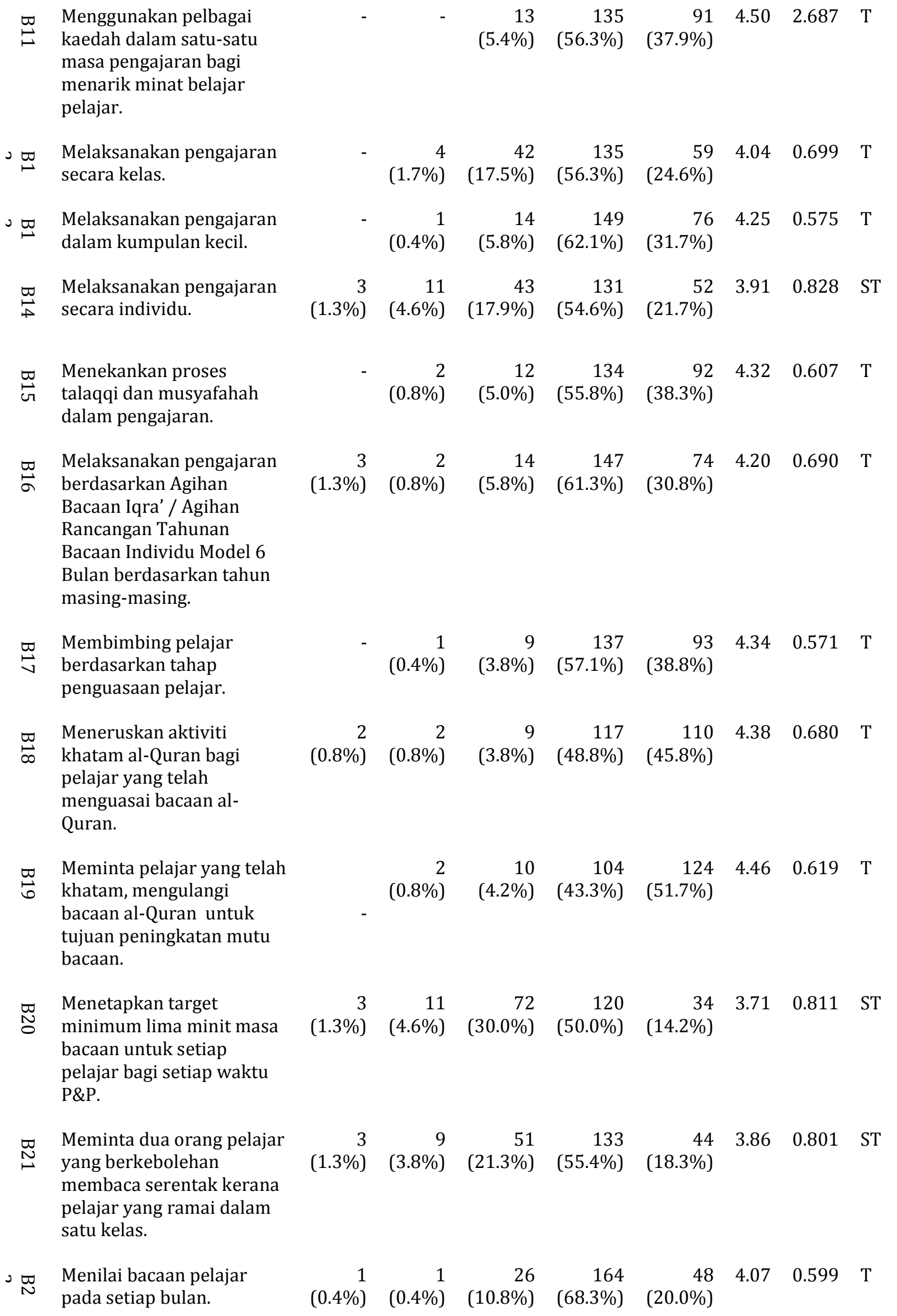




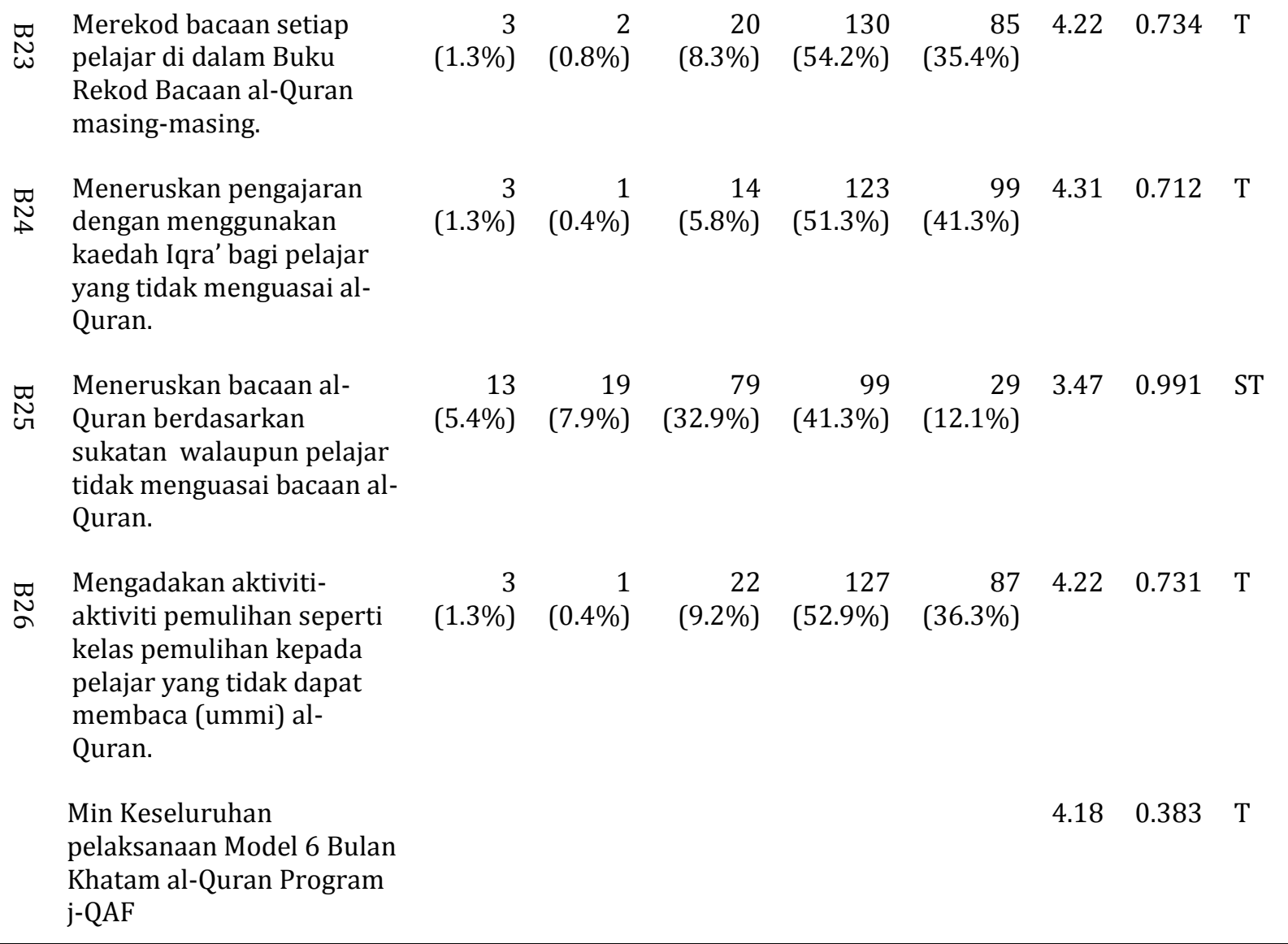

\section{b. Pelaksanaan Pengajaran Tilawah al-Quran Program j-QAF (Model Tasmik)}

Bagi menjawab persoalan kajian yang kedua, sebanyak 22 item telah digunakan merangkumi penilaian pelaksanaan terhadap objektif, isi kandungan dan pelaksanaan Model Tasmik.

Jadual 5: Penilaian Guru Terhadap Pelaksanaan Model Tasmik

\begin{tabular}{|c|c|c|c|c|c|c|c|c|c|}
\hline \multirow{2}{*}{$z$} & \multirow{2}{*}{ Item } & \multicolumn{5}{|c|}{ Kekerapan \& Peratus(N=240) } & \multirow{2}{*}{ Min } & \multirow{2}{*}{ SP } & \multirow{2}{*}{ INT } \\
\hline & & STS & TS & KS & $\mathbf{S}$ & SS & & & \\
\hline$\stackrel{\mathbb{N}}{\mathrm{N}}$ & $\begin{array}{l}\text { Mengetahui objektif } \\
\text { pelaksanaan Model } \\
\text { Tasmik. }\end{array}$ & 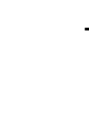 & - & $\begin{array}{r}12 \\
(5.0 \%)\end{array}$ & $\begin{array}{r}161 \\
(67.1 \%)\end{array}$ & $\begin{array}{r}67 \\
(27.9 \%)\end{array}$ & 4.23 & 0.527 & $\mathrm{~T}$ \\
\hline$\underset{\infty}{\infty}$ & $\begin{array}{l}\text { Memastikan objektif } \\
\text { tercapai selepas proses } \\
\text { P\&P Model Tasmik. }\end{array}$ & . & - & $\begin{array}{r}17 \\
(7.1 \%)\end{array}$ & $\begin{array}{r}167 \\
(69.6 \%)\end{array}$ & $\begin{array}{r}56 \\
(23.3 \%)\end{array}$ & 4.16 & 0.528 & $\mathrm{~T}$ \\
\hline$\underset{\widetilde{J}}{\mathbb{N}}$ & $\begin{array}{l}\text { Mengetahui dengan jelas } \\
\text { cara melaksanakan Model } \\
\text { Tasmik. }\end{array}$ & . & - & $\begin{array}{r}24 \\
(10.0 \%)\end{array}$ & $\begin{array}{r}160 \\
(66.7 \%)\end{array}$ & $\begin{array}{r}56 \\
(23.3 \%)\end{array}$ & 4.13 & 0.563 & $\mathrm{~T}$ \\
\hline 0 & $\begin{array}{l}\text { Melaksanakan Model } \\
\text { Tasmik di sekolah. }\end{array}$ & . & $\begin{array}{r}1 \\
(0.4 \%)\end{array}$ & $\begin{array}{r}14 \\
(5.8 \%)\end{array}$ & $\begin{array}{r}149 \\
(62.1 \%)\end{array}$ & $\begin{array}{r}76 \\
(31.7 \%)\end{array}$ & 4.25 & 0.575 & $\mathrm{~T}$ \\
\hline
\end{tabular}


ש. Melaksanakan Model

$\stackrel{\omega}{\omega}$ Tasmik di luar kawasan sekolah.

๒ Melaksanakan Model

心 Tasmik di luar waktu persekolahan.

๒ Melaksanakan Model

$\omega$ w Tasmik kepada semua pelajar yang beragama Islam dari tahun 1 hingga tahun 6.

$\begin{array}{ll}\varpi & \text { Melaksanakan Model } \\ \oplus & \text { Tasmik hanya kepada }\end{array}$ pelajar-pelajar yang belum menguasai bacaan al-Quran.

\urcorner$\underset{\omega}{\varpi}$ Melaksanakannya secara individu.

$\varpi$ Melaksanakannya

๙ berdasarkan jadual waktu yang telah ditetapkan.

ง ๒ Menggunakan kaedah talaqqi dan musyafahah.

ఊ Menggunakan kaedah

$\omega_{\infty}$ latih tubi dan pengulangan.

๒ Melaksanakannya di bilik

wु khas/bilik yang sesuai.

$\begin{array}{ll}\square & \text { Memerlukan guru } \\ \stackrel{f}{\circ} & \text { pembimbing dilantik oleh }\end{array}$ pihak sekolah.

$\varpi$ Memerlukan Guru daripada guru j-QAF, guru Pendidikan Islam dan guru akademik yang mahir membaca al-Quran.

চr Menjadikan pelajar yang telah khatam al-Quran sebagai pembantu guru pembimbing.

ए Membimbing bacaan dan $\stackrel{\oplus}{\omega}$ merekod bacaan pelajar dalam Buku Rekod Bacaan setiap kali ditasmik.
$\begin{array}{llllllll}16 & 21 & 73 & 93 & 37 & 3.48 & 1.067 & \text { ST }\end{array}$
$\begin{array}{lllll}(6.7 \%) & (8.8 \%) & (30.4 \%) & (38.8 \%) & (15.4 \%)\end{array}$

$\begin{array}{rrrrrrrr}3 & 7 & 24 & 138 & 68 & 4.09 & 0.779 & \mathrm{~T} \\ (1.3 \%) & (2.9 \%) & (10.0 \%) & (57.5 \%) & (28.3 \%) & & & \\ 1 & 2 & 9 & 146 & 82 & 4.28 & 0.613 & \mathrm{~T} \\ (0.4 \%) & (0.8 \%) & (3.8 \%) & (60.8 \%) & (34.2 \%) & & & \end{array}$

$\begin{array}{rrrrrrrr}1 & 1 & 12 & 144 & 82 & 4.27 & 0.612 & \mathrm{~T} \\ (0.4 \%) & (0.4 \%) & (5.0 \%) & (60.0 \%) & (34.2 \%) & & & \\ 1 & 3 & 18 & 151 & 67 & 4.17 & 0.645 & \mathrm{~T} \\ (0.4 \%) & (1.3 \%) & (7.5 \%) & (62.9 \%) & (27.9 \%) & & & \\ & & & & & & & \\ 3 & 3 & 23 & 136 & 75 & 4.15 & 0.741 & \mathrm{~T} \\ (1.3 \%) & (1.3 \%) & (9.6 \%) & (56.7 \%) & (31.3 \%) & & & \end{array}$

$\begin{array}{llllllll}2 & 4 & 16 & 158 & 60 & 4.13 & 0.667 & \mathrm{~T}\end{array}$

$\begin{array}{lllll}(0.8 \%) & (1.7 \%) \quad(6.7 \%) & (65.8 \%) & (25.0 \%)\end{array}$
$\begin{array}{rrrrrrrr}4 & 5 & 27 & 137 & 67 & 4.08 & 0.789 & \mathrm{~T}\end{array}$
$(1.7 \%) \quad(2.1 \%) \quad(11.3 \%) \quad(57.1 \%) \quad(27.9 \%)$




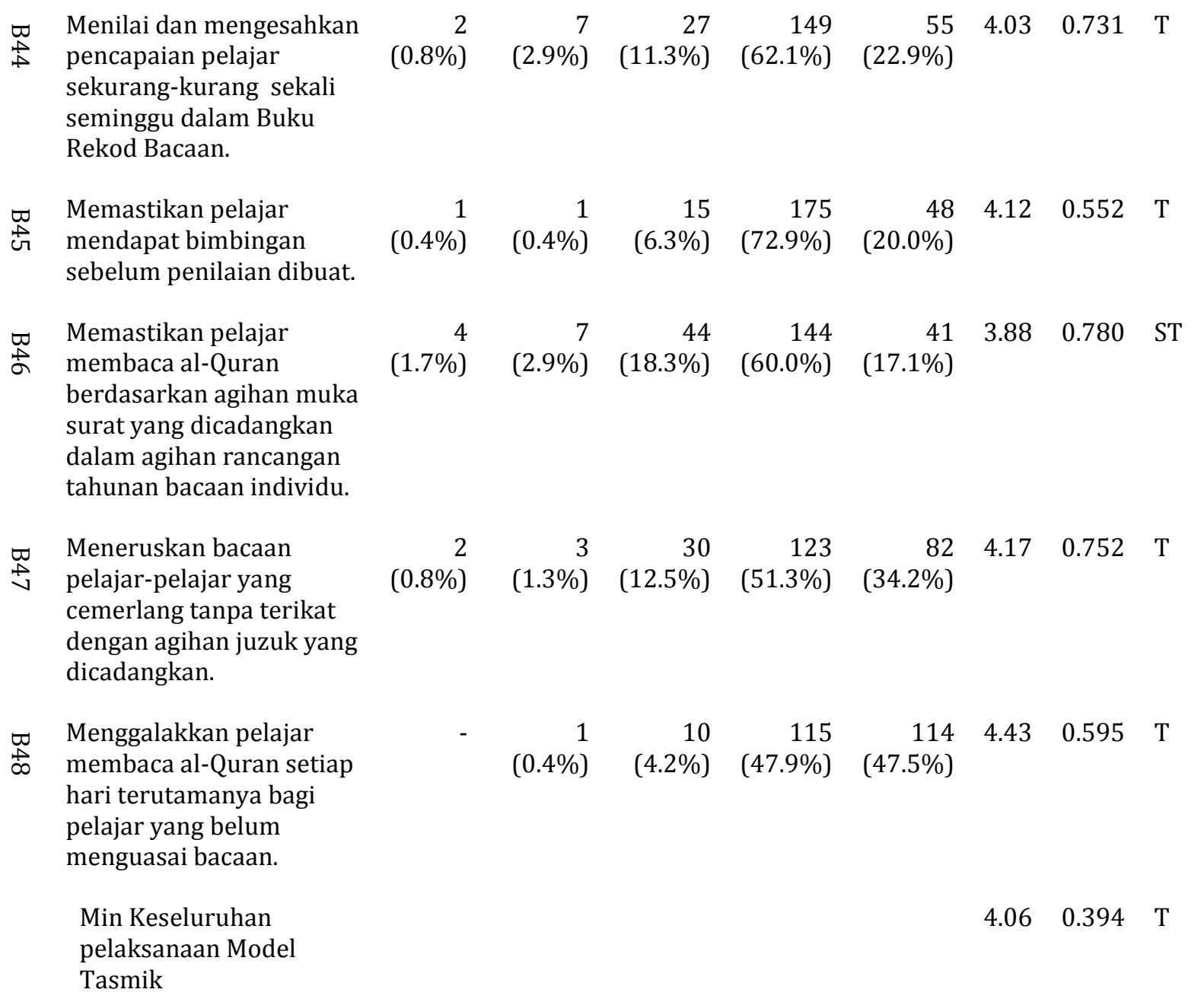

\section{c. Pelaksanaan Pengajaran Tilawah al-Quran Program j-QAF (Asuhan Tilawah al- Quran)}

Asuhan Tilawah al-Quran adalah merujuk kepada sukatan pelajaran Asuhan Tilawah al-Quran KBSR yang dikekalkan dalam program j-QAF dan dilaksanakan pada 6 bulan kedua. Hasil dapatan yang diperolehi dihuraikan seperti berikut:

Jadual 6: Penilaian Guru Terhadap Pelaksanaan Model Asuhan Tilawah al-Quran

\begin{tabular}{|c|c|c|c|c|c|c|c|c|c|}
\hline \multirow{2}{*}{ z } & \multirow{2}{*}{ Item } & \multicolumn{5}{|c|}{ Kekerapan \& Peratus $(\mathrm{N}=240)$} & \multirow{2}{*}{ Min } & \multirow{2}{*}{ SP } & \multirow{2}{*}{ INT } \\
\hline & & STS & TS & KS & $\mathbf{S}$ & SS & & & \\
\hline  & $\begin{array}{l}\text { Mengetahui objektif } \\
\text { pengajaran Asuhan } \\
\text { Tilawah al-Quran } \\
\text { dengan jelas. } 1\end{array}$ & . & & $\begin{array}{r}6 \\
(2.5 \%)\end{array}$ & $\begin{array}{r}138 \\
(57.5 \%)\end{array}$ & $\begin{array}{r}95 \\
(39.6 \%)\end{array}$ & 4.54 & 2.676 & $\mathrm{~T}$ \\
\hline 品 & $\begin{array}{l}\text { Mengetahui objektif } \\
\text { yang perlu dicapai di } \\
\text { akhir P\&P Asuhan } \\
\text { Tilawah al-Quran. } 2\end{array}$ & . & & $\begin{array}{r}7 \\
(2.9 \%)\end{array}$ & $\begin{array}{r}141 \\
(58.8 \%)\end{array}$ & $\begin{array}{r}92 \\
(38.3 \%)\end{array}$ & 4.35 & 0.537 & $\mathrm{~T}$ \\
\hline
\end{tabular}


Ab. Halim Tamuri et.al.

$\begin{array}{ll}\underset{⿴ 囗 十}{\varpi} & \text { Merancang dan } \\ & \text { melaksanakan P\&P }\end{array}$ berdasarkan objektif yang telah ditetapkan. 3

ఝ্লে Mengajar Asuhan

N Tilawah al-Quran pada enam bulan kedua (Julai hingga Disember).4

Ф Mengajar sebanyak tiga

๗ waktu untuk tahun satu dan dua waktu untuk tahun dua hingga tahun enam.5

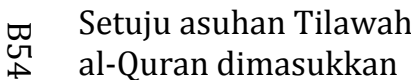
dalam jadual waktu persekolahan biasa. 6

Mengenal pasti tahap ज penguasaan bacaan alQuran pelajar. 7

$\varpi \quad$ Menggunakan

๙ musyafahah dalam pengajaran. 8

$\varpi \quad$ Memberi tumpuan pengajaran kepada tiga kemahiran pelajar iaitu bacaan, hafazan dan kefahaman. 9

- Mengaitkan pengajaran ऽ dengan kehidupan pelajar. 10

চ Tidak menekankan जु hukum tajwid secara khusus dalam pengajaran. 11

$\square \quad$ Menekankan bacaan al-

o Quran yang betul berdasarkan hukum tajwid. 12

চ్ Meraikan pelajar aras satu melalui pengajaran yang masih menyentuh aspek sebutan kalimah dan keratan ayat.13
$(0.4 \%)$
5
154
$\begin{array}{llll}80 & 4.30 & 0.529 & \mathrm{~T}\end{array}$
(2.1\%) (64.2\%) (33.3\%)

$\begin{array}{rrrrrrrr}3 & 4 & 14 & 141 & 78 & 4.20 & 0.725 & \mathrm{~T} \\ (1.3 \%) & (1.7 \%) & (5.8 \%) & (58.8 \%) & (32.5 \%) & & & \end{array}$

$\begin{array}{rrrrrrrr}5 & 5 & 17 & 142 & 71 & 4.12 & 0.791 & \mathrm{~T} \\ (2.1 \%) & (2.1 \%) & (7.1 \%) & (59.2 \%) & (29.6 \%) & & & \end{array}$

$\begin{array}{rrrrrrr}2 & 5 & 132 & 101 & 4.38 & 0.574 & \mathrm{~T} \\ (0.8 \%) & (2.1 \%) & (55.0 \%) & (42.1 \%) & & & \end{array}$

$(0.8 \%) \quad(2.5 \%) \quad(60.4 \%) \quad(36.3 \%)$

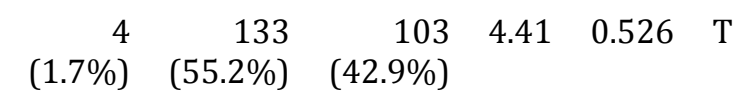
$\begin{array}{llllll}11 & 138 & 91 & 4.33 & 0.561 & \mathrm{~T}\end{array}$
$(4.6 \%) \quad(57.5 \%) \quad(37.9 \%)$ T 
Min Keseluruhan

pelaksanaan Asuhan

Tilawah al-Quran

\section{d. Pelaksanaan Pengajaran Tilawah al-Quran Program j-QAF (Kem Literasi al-Quran)}

Kem Literasi al-Quran adalah merujuk kepada modul susulan yang dilaksanakan bagi mengatasi masalah keciciran penguasaan al-Quran di kalangan pelajar. Hasil dapatan yang diperolehi bagi model ini dihuraikan seperti berikut:

Jadual 7: Penilaian Guru Terhadap Pelaksanaan Kem Literasi al-Quran

\begin{tabular}{|c|c|c|c|c|c|c|c|c|c|}
\hline \multirow{2}{*}{$z$} & \multirow{2}{*}{ Item } & \multicolumn{5}{|c|}{ Kekerapan \& Peratus $(\mathrm{N}=\mathbf{2 4 0 0})$} & \multirow{2}{*}{ Min } & \multirow{2}{*}{ SP } & \multirow{2}{*}{ INT } \\
\hline & & STS & TS & KS & S & SS & & & \\
\hline $\begin{array}{l}\text { ్ָ } \\
\text { S }\end{array}$ & $\begin{array}{l}\text { Mengetahui matlamat Kem } \\
\text { Literasi al-Quran dengan } \\
\text { jelas. }\end{array}$ & - & $\begin{array}{r}5 \\
(2.1 \%)\end{array}$ & $\begin{array}{r}21 \\
(8.86 \%)\end{array}$ & $\begin{array}{r}142 \\
(59.2 \%)\end{array}$ & $\begin{array}{r}72 \\
(30.0 \%)\end{array}$ & 4.17 & 0.666 & $\mathrm{~T}$ \\
\hline Фூ & $\begin{array}{l}\text { Melibatkan pelajar yang } \\
\text { belum menguasai bacaan } \\
\text { Iqra' } 1 \text { hingga } 3 \text { sebagai } \\
\text { peserta KLAQ. }\end{array}$ & - & - & $\begin{array}{r}19 \\
(7.9 \%)\end{array}$ & $\begin{array}{r}140 \\
(58.3 \%)\end{array}$ & $\begin{array}{r}81 \\
(33.8 \%)\end{array}$ & 4.26 & 0.593 & $\mathrm{~T}$ \\
\hline চ্ণ & $\begin{array}{l}\text { Membimbing pelajar } \\
\text { sekurang-kurangnya } \\
\text { mencapai Iqra' } 4 \text { dan } \\
\text { selepas itu diteruskan } \\
\text { bacaan. }\end{array}$ & - & $\begin{array}{r}1 \\
(0.4 \%)\end{array}$ & $\begin{array}{r}17 \\
(7.1 \%)\end{array}$ & $\begin{array}{r}154 \\
(64.2 \%)\end{array}$ & $\begin{array}{r}68 \\
(28.3 \%)\end{array}$ & 4.20 & 0.575 & $\mathrm{~T}$ \\
\hline $\begin{array}{l}\text { बू } \\
\text { जे }\end{array}$ & $\begin{array}{l}\text { Melibatkan tenaga } \\
\text { penggerak kem adalah } \\
\text { guru j-QAF dan GPI. }\end{array}$ & $\begin{array}{r}4 \\
(1.7 \%)\end{array}$ & $\begin{array}{r}4 \\
(1.7 \%)\end{array}$ & $\begin{array}{r}19 \\
(7.9 \%)\end{array}$ & $\begin{array}{r}130 \\
(54.2 \%)\end{array}$ & $\begin{array}{r}83 \\
(34.6 \%)\end{array}$ & 4.18 & 0.781 & $\mathrm{~T}$ \\
\hline $\begin{array}{l}\text { ஜू } \\
\text { बे }\end{array}$ & $\begin{array}{l}\text { Melibatkan pelajar turus } \\
\text { digunakan bagi membantu } \\
\text { guru. }\end{array}$ & - & $\begin{array}{r}4 \\
(1.7 \%)\end{array}$ & $\begin{array}{r}16 \\
(6.7 \%)\end{array}$ & $\begin{array}{r}137 \\
(57.1 \%)\end{array}$ & $\begin{array}{r}83 \\
(34.6 \%)\end{array}$ & 4.25 & 0.648 & $\mathrm{~T}$ \\
\hline ஜू & $\begin{array}{l}\text { Melaksanakan Kem } \\
\text { Literasi al-Quran } \\
\text { dilaksanakan selama } 16 \\
\text { jam. }\end{array}$ & $\begin{array}{r}2 \\
(0.8 \%)\end{array}$ & $\begin{array}{r}6 \\
(2.5 \%)\end{array}$ & $\begin{array}{r}60 \\
(25.0 \%)\end{array}$ & $\begin{array}{r}117 \\
(48.8 \%)\end{array}$ & $\begin{array}{r}55 \\
(22.9 \%)\end{array}$ & 3.90 & 0.805 & ST \\
\hline 0 पू & $\begin{array}{l}\text { Melaksanakan di luar } \\
\text { waktu persekolahan. }\end{array}$ & $\begin{array}{r}4 \\
(1.7 \%)\end{array}$ & $\begin{array}{r}12 \\
(5.0 \%)\end{array}$ & $\begin{array}{r}41 \\
(17.1 \%)\end{array}$ & $\begin{array}{r}135 \\
(56.3 \%)\end{array}$ & $\begin{array}{r}48 \\
(20.0 \%)\end{array}$ & 3.88 & 0.842 & ST \\
\hline प్ర్య & $\begin{array}{l}\text { Membahagikan pelajar } \\
\text { kepada kumpulan kecil } \\
\text { antara } 3 \text { hingga } 5 \text { orang. }\end{array}$ & - & $\begin{array}{r}3 \\
(1.3 \%)\end{array}$ & $\begin{array}{r}19 \\
(7.9 \%)\end{array}$ & $\begin{array}{r}149 \\
(62.1 \%)\end{array}$ & $\begin{array}{r}69 \\
(28.8 \%)\end{array}$ & 4.18 & 0.620 & $\mathrm{~T}$ \\
\hline 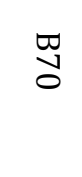 & $\begin{array}{l}\text { Memastikan kumpulan } \\
\text { terdapat seorang } \\
\text { fasilitator/pembimbing } \\
\text { yang berkemahiran. }\end{array}$ & - & $\begin{array}{r}2 \\
(0.8 \%)\end{array}$ & $\begin{array}{r}13 \\
(5.4 \%)\end{array}$ & $\begin{array}{r}144 \\
(60.0 \%)\end{array}$ & $\begin{array}{r}81 \\
(33.8 \%)\end{array}$ & 4.27 & 0.596 & $\mathrm{~T}$ \\
\hline
\end{tabular}


Ab. Halim Tamuri et.al.

$\underset{J}{\varpi}$ mengenal pasti tahap bacaan pelajar sebelum KLAQ (muka surat buku Iqra').

$\begin{array}{ll}\underset{N}{N} & \text { Membimbing pelajar } \\ \text { selama } 10 \text { jam untuk buku }\end{array}$ Iqra' 1 dan 2, manakala 6 jam untuk buku Iqra' 3 .

$\square$ Membentuk jawatankuasa ๗ు pelaksana Kem Literasi alQuran.

- ๒ Menyediakan Aliran Kerja Pelaksana.

שु Mengenal pasti dan

ज merekodkan tahap penguasaan bacaan pelajar sebelum mengikuti KLAQ.

Ð Menggunakan modul khas নু bagi meningkatkan tahap penguasaan pelajar.

שु Menekankan pendekatan ป talaqqi dan musyafahah dalam pengajaran.

$\varpi \quad$ Menunjukkan contoh $\bowtie$ bacaan dengan betul, jelas dan fasih kepada pelajar.

$\varpi \quad$ Menjelaskan konsep

ปु pengajaran dari mudah ke lebih kompleks.

- Memberi galakan dan $\stackrel{\infty}{\circ}$ motivasi kepada pelajar bagi meningkatkan usaha mereka untuk menguasai bacaan al-Quran.

Ф्) Meminta pelajar menyebut $\stackrel{\infty}{\ominus}$ huruf atau kalimah secara berulang-ulang untuk tujuan hafalan.

ष्) Tidak menggunakan cara paksaan atau merotan supaya pelajar membaca.

$\varpi$ kaedah dan teknik bagi

$\begin{array}{rrrrrrr}1 & 13 & 156 & 70 & 4.23 & 0.558 & \mathrm{~T} \\ (0.4 \%) & (5.4 \%) & (65.0 \%) & (29.2 \%) & & & \end{array}$

$\begin{array}{rrrrrrrr}2 & 4 & 45 & 147 & 42 & 3.93 & 0.708 & \text { ST } \\ (0.8 \%) & (1.7 \%) & (18.8 \%) & (61.3 \%) & (17.5 \%) & & & \end{array}$

$\begin{array}{rrrrrrrr}1 & 1 & 25 & 148 & 65 & 4.15 & 0.640 & \mathrm{~T} \\ (0.4 \%) & (0.4 \%) & (10.4 \%) & (61.7 \%) & (27.1 \%) & & & \\ & & & & & & & \\ 2 & 6 & 14 & 166 & 52 & 4.08 & 0.667 & \mathrm{~T} \\ (0.8 \%) & (2.5 \%) & (5.8 \%) & (69.2 \%) & (21.7 \%) & & & \\ - & 1 & 13 & 161 & 65 & 4.21 & 0.547 & \mathrm{~T} \\ & (0.4 \%) & (5.4 \%) & (67.1 \%) & (27.1 \%) & & & \end{array}$

$\begin{array}{llll}(7.5 \%) \quad(66.3 \%) \quad(26.3 \%) & \mathrm{T}\end{array}$

$\begin{array}{rrrrrr}13 & 141 & 86 & 4.30 & 0.567 & \mathrm{~T} \\ (5.4 \%) & (58.8 \%) & (35.8 \%) & & & \end{array}$

$\begin{array}{rrrrrrr}1 & 9 & 128 & 102 & 4.38 & 0.580 & \mathrm{~T} \\ (0.4 \%) & (3.8 \%) & (53.3 \%) & (42.5 \%) & & & \end{array}$

$\begin{array}{rrrrrr}11 & 141 & 88 & 4.32 & 0.558 & \mathrm{~T} \\ (4.6 \%) & (58.8 \%) & (36.7 \%) & & & \end{array}$
$\begin{array}{llllll}8 & 128 & 104 & 4.40 & 0.555 & \mathrm{~T}\end{array}$
$(3.3 \%) \quad(53.3 \%) \quad(43.3 \%)$

$\begin{array}{rrrrrrr}1 & 16 & 135 & 88 & 4.29 & 0.605 & \text { ST } \\ (0.4 \%) & (6.7 \%) & (56.3 \%) & (36.7 \%) & & & \end{array}$

$\begin{array}{rrrrrrrr}1 & 7 & 29 & 149 & 54 & 4.03 & 0.708 & \text { ST } \\ (0.4 \%) & (2.9 \%) & (12.1 \%) & (62.1 \%) & (22.5 \%) & & & \\ - & & & & & & & \\ & 1 & 10 & 140 & 89 & 4.32 & 0.572 & \mathrm{~T}\end{array}$




$$
\begin{aligned}
& \underset{\infty}{\infty} \text { Menggunakan bahan bantu } \\
& \stackrel{\text { mengajar yang menarik }}{\text { minat pelajar. }}
\end{aligned}
$$

ᄀ 마 Menggunakan bahan bantu mengajar berasaskan TMK.

$\square$ Merekodkan bacaan akhir

๙ pelajar selepas mengikuti KLAQ dengan menggunakan borang rekod pencapaian Iqra'.

$\underset{\infty}{\infty}$ Menganalisa data

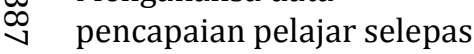
mengikuti KLAQ.

$\begin{array}{ll}\mathscr{\infty} & \text { Mengemaskini rekod } \\ \infty & \text { bacaan meyimpan di dalam } \\ & \text { fail khas Kem Literasi al- }\end{array}$

Quran untuk tujuan

rujukan.

Min Keseluruhan

\begin{tabular}{|c|c|c|c|c|c|c|c|}
\hline - & $\begin{array}{r}2 \\
(0.8 \%)\end{array}$ & $\begin{array}{r}18 \\
(7.5 \%)\end{array}$ & $\begin{array}{r}146 \\
(60.8 \%)\end{array}$ & $\begin{array}{r}74 \\
(30.8 \%)\end{array}$ & 4.22 & 0.609 & $\mathrm{~T}$ \\
\hline $\begin{array}{r}1 \\
(0.4 \%)\end{array}$ & $\begin{array}{r}4 \\
(1.7 \%)\end{array}$ & $\begin{array}{r}30 \\
(12.5 \%)\end{array}$ & $\begin{array}{r}146 \\
(60.8 \%)\end{array}$ & $\begin{array}{r}59 \\
(24.6 \%)\end{array}$ & 4.08 & 0.687 & $\mathrm{~T}$ \\
\hline - & $\begin{array}{r}2 \\
(0.8 \%)\end{array}$ & $\begin{array}{r}14 \\
(5.8 \%)\end{array}$ & $\begin{array}{r}152 \\
(63.3 \%)\end{array}$ & $\begin{array}{r}72 \\
(30.0 \%)\end{array}$ & 4.22 & 0.585 & ST \\
\hline - & $\begin{array}{r}1 \\
(0.4 \%)\end{array}$ & $\begin{array}{r}17 \\
(7.1 \%)\end{array}$ & $\begin{array}{r}159 \\
(66.3 \%)\end{array}$ & $\begin{array}{r}63 \\
(26.3 \%)\end{array}$ & 4.18 & 0.564 & $\mathrm{~T}$ \\
\hline $\begin{array}{r}1 \\
(0.4 \%)\end{array}$ & $\begin{array}{r}1 \\
(0.4 \%)\end{array}$ & $\begin{array}{r}14 \\
(5.8 \%)\end{array}$ & $\begin{array}{r}147 \\
(61.3 \%)\end{array}$ & $\begin{array}{r}76 \\
(31.7 \%)\end{array}$ & 4.41 & 2.701 & $\mathrm{~T}$ \\
\hline & & & & & 4.19 & 0.446 & $\mathrm{~T}$ \\
\hline
\end{tabular}

pelaksanaan Kem Literasi

al-Quran

Ujian Korelasi Pearson dijalankan untuk melihat hubungan pelaksanaan model-model jQAF berdasarkan penilaian guru-guru pendidikan Islam dan j-QAF. Berikut adalah dapatan ujian yang dijalankan.

Jadual 8: Korelasi Antara Pelaksanaan Model-Model Tilawah Al-Quran

\begin{tabular}{lll}
\hline & Pemboleh ubah & R. \\
\hline Modul 6 Bulan Khatam al-Quran*Pengajaran Tilawah-al-Quran j-QAF & $* 0$ \\
Modul Tasmik*Pengajaran Tilawah-al-Quran j-QAF & $i^{*}$ & 0 \\
Asuhan Tilawah al-Quran*Pengajaran Tilawah-al-Quran j-QAF & i & 0 \\
Kem Literasi*Pengajaran Tilawah-al-Quran j-QAF & $*$ & 0 \\
\hline
\end{tabular}

*Signifikan pada aras $\mathrm{p}<0.01$

Analisis korelasi Pearson dijalankan bagi mengenal pasti tahap hubungan antara modelmodel dengan pelaksanaan pengajaran Tilawah al-Quran jQAF. Dapatan menunjukkan terdapat hubungan yang kuat antara 4 model j-QAF dengan pelaksanaan Tilawah al-Quran j-QAF iaitu Modul 6 Bulan Khatam al-Quran dan Pengajaran Tilawah-al-Quran j-QAF ( $r=.877$, sig.=.000), Modul Tasmik dan Pengajaran Tilawah-al-Quran j-QAF ( $\mathrm{r}=.846$, sig.=.000), Asuhan Tilawah alQuran dan Pengajaran Tilawah-al-Quran j-QAF ( $r=.869$, sig.=.000), Kem Literasi dan Pengajaran Tilawah-al-Quran j-QAF, ( $r=.864$., sig.=.000).

\section{Perbincangan}

Berdasarkan hasil kajian didapati tahap pelaksanaan pengajaran Tilawah al- Quran Program jQAF bagi Model 6 Bulan Khatam al-Quran berada pada tahap tinggi dengan purata min 4.18. Ini menunjukkan bahawa tahap pelaksanaan pengajaran Tilawah al-Quran program j-QAF bagi Model 6 Bulan Khatam al-Quran di sekolah-sekolah kebangsaan berkenaan berada pada tahap yang memuaskan guru-guru. Penilaian dari aspek konteks, berdasarkan 3 item yang dinilai iaitu item B1 'Memahami dengan jelas objektif Model 6 Bulan Khatam al-Quran', item B3 
'Melaksanakan pengajaran berdasarkan objektif pengajaran' dan item B4 'Memastikan di akhir $P \& P$, pelajar dapat menguasai objektif pengajaran dengan baik' adalah berada pada tahap tinggi. Kefahaman yang tinggi terhadap matlamat dan objektif pengajaran adalah perkara yang paling penting dikuasai oleh guru-guru sebelum melaksanakan pengajaran. Ini kerana ia menjadi hala tuju serta menentukan pendekatan, strategi dan teknik yang digunakan dalam proses P\&P.

Dari aspek pengetahuan dan kefahaman guru terhadap isi kandungan sukatan pelajaran, peruntukan waktu mengajar dan bahan bantu yang diperlukan sepanjang proses P\&P bagi Model 6 Bulan Khatam al-Quran, guru-guru melihat aspek ini dapat dilaksanakan di sekolah. Item B2 menunjukkan bahawa pelajar-pelajar tahun 1 hingga 6 akan mengikuti P\&P Model 6 Bulan Khatam al-Quran bermula dari bulan Januari hingga Jun. Namun untuk mencapai hasrat untuk memenuhi matlamat yang ditetapkan bukan semudah yang disangka malah ia perlu diteliti dan difahami dengan sepenuhnya kerana hasil dapatan yang telah diperoleh daripada kajian-kajian lepas yang telah dijalankan, mendapati pelajar masih tidak mampu menguasai kemahiran membaca al-Quran walaupun telah melalui enam tahun pembelajaran di sekolah rendah (Mohd Aderi 2004; Mohd Aderi \& Rohani 2009).

Pelaksanaan kaedah talaqqi dan musyafahah penting dalam melaksanakan model ini. Hasil dapatan tersebut membuktikan bahawa terdapat kebanyakan guru turut menggunakan kaedah-kaedah lain tanpa mengesampingkan kaedah talaqqi dan musyafahah dalam proses P\&P. Namun, kaedah talaqqi dan musyafahah tetap menjadi kaedah yang paling utama. Penggunaan pelbagai kaedah dalam proses P\&P mampu menarik minat dan mengekalkan tumpuan pelajar mengikuti proses tersebut. Walau bagaimanapun hasil dapatan ini juga menunjukkan bahawa masih wujud dalam kalangan guru yang tidak menggunakan dan menekankan kaedah talaqqi dan musyafahah di dalam proses P\&P. Inilah antara sebab utama masalah ketidak mampuan pelajar-pelajar menguasai bacaan al-Quran masih berlanjutan tanpa ada jalan penyelesaiannya walaupun telah mengikuti proses P\&P tilawah al-Quran program jQAF selama 6 tahun di sekolah rendah sebagaimana hasil kajian Mohd Aderi \& Rohani (2009) yang memfokuskan tentang kelemahan penguasaan kemahiran membaca al-Quran kalangan pelajar walaupun mereka telah melalui enam tahun pembelajaran di sekolah rendah. Oleh sebab itu, semua guru khususnya guru pendidikan tilawah al-Quran perlu menekankan juga dari aspek pemilihan dan penggunaan kaedah yang berkesan dalam proses P\&P. Kaedah pengajaran serta cara penyampaian kaedah yang bersistematik sangat mempengaruhi proses penerimaan pelajar terhadap pengajaran guru. Dengan menggunakan kaedah yang baik dan sesuai, ia mampu membantu pelajar memperoleh ilmu pengetahuan, kemahiran dan membawa perubahan sikap dan tingkah laku, menanam minat dan nilai-nilai yang diingini (Kamarul Azmi \& Ab. Halim 2012).

Berdasarkan dapatan kajian, tahap pelaksanaan pengajaran tilawah al-Quran Model Tasmik berada pada tinggi iaitu mencapai skor min 4.06. Hasil dapatan menunjukkan majoriti responden mengetahui dan memahami dengan jelas objektif pelaksanaan Model Tasmik yang dijalankan. Walaupun begitu, masih terdapat sebilangan kecil guru yang kurang mengetahui objektif model tasmik dan kurang memastikan objektif tercapai selepas ia dilaksanakan. Keadaan ini boleh menyebabkan kemungkinan tidak mencapai objektif yang ditetapkan adalah besar kerana guru sendiri tidak mengetahui matlamat dan objektif Model Tasmik dilaksanakan sedangkan objektif yang telah digariskan oleh KPM bagi Model Tasmik ialah pelajar dapat membaca al-Quran dengan bertajwid dan dapat mengkhatamkan bacaan al-Quran 30 juzuk. Kebanyakan guru melaksanakan model tasmik atau mendengar bacaan pelajar berdasarkan apa yang telah dipelajari sewaktu proses P\&P dilaksanakan berdasarkan tahap penguasaan pelajar. Ia adalah satu tindakan yang sewajarnya dilakukan oleh guru iaitu dengan mengajar dan membimbing pelajar berdasarkan aras pengetahuan pelajar dan dipelajari sewaktu P\&P tilawah al-Quran dalam waktu persekolahan.

Kajian ini mendapati agihan muka surat yang dicadangkan adalah tidak sesuai kepada semua pelajar. Ketidaksesuaian ini berlaku disebabkan terdapat tahap penguasaan pelajar berbeza-beza antara satu sama lain. Ada kalangan pelajar yang terlalu lemah dan tidak mampu menguasai pelajaran di dalam muka surat yang dicadangkan. Manakala terdapat juga pelajar 
yang telah menguasai dengan baik bacaan Iqra'/al-Quran dan meneruskan bacaan Iqra'/alQuran mendahului agihan muka surat yang dicadangkan. Keadaan yang berlaku adalah normal di mana-mana sekolah kerana mustahil semua pelajar dilahirkan pandai dan setara. Pasti terdapat pelajar yang bijak, sederhana, lemah dan ada juga yang terlalu lemah.

Namun guru seharusnya berusaha paling kurang semua pelajar dapat mengikuti agihan bacaan yang telah dicadangkan di samping melaksanakan aktiviti-aktiviti pemulihan dan pengukuhan secara berterusan dalam kalangan pelajar yang masih tidak dapat menguasainya. Ini adalah kerana agihan bacaan tersebut telah disusun dengan rapi mengikut tahun sehinggalah khatam pada hujung bulan Jun bagi tahun 6 . Melalui tasmik, guru seharusnya dapat mengenal pasti pelajar yang mampu menguasai pengajaran atau tidak. Bagi pelajar yang masih tidak menguasainya, perlu diambil tindakan dan mencari jalan penyelesaian bagi mengatasi permasalahan ini.

Dari segi masa pelaksanaannya pula, aktiviti tasmik perlu dilaksanakan di luar jadual waktu persekolahan. Ini bermakna jadual waktu tasmik tidak termasuk di dalam jadual waktu persekolahan. Walaupun begitu terdapat ramai juga yang kurang bersetuju dengan penetapan waktu tasmik di luar jadual waktu persekolahan. Keadaan ini berlaku mungkin disebabkan kekangan-kekangan yang dihadapi hingga menyebabkan ia tidak dapat dilaksanakan secara menyeluruh. Antara kekangan yang terpaksa dihadapi adalah kekurangan tenaga guru, masa yang terhad, masalah pengangkutan, komitmen ibu bapa dan sebagainya. Pelaksanaan tasmik di dalam kawasan sekolah dapat memudahkan aktiviti tasmik dijalankan. Ia akan berjalan dengan lebih tersusun dan dapat dipantau pelaksanaannya dengan mudah. Sekiranya aktiviti tasmik ini dilaksanakan di luar kawasan sekolah, ia menyukarkan pelaksanaannya kerana ia melibatkan guru, pelajar, masa dan tempat yang berbeza.

Penggunaan kaedah talaqqi dan musyafahah juga adalah kaedah utama yang sangat perlu dilaksanakan dalam model tasmik yang dipersetujui oleh hampir keseluruhan responden. Selain itu, hasil dapatan menunjukkan kebanyakan responden juga menggunakan kaedah latih tubi dan pengulangan ketika tasmik. Bagi memastikan aktiviti tasmik dapat dilaksanakan secara berkesan, tenaga guru yang ramai perlu dilibatkan bagi memastikan semua pelajar dapat menguasai bacaan al-Quran dengan baik. Namun bilangan guru j-QAF dan guru Pendidikan Islam yang ada tidak mampu untuk melakukan tasmik keseluruhan pelajar di sekolah. Bagi mengatasi masalah ini, kebanyakan responden bersetuju selain daripada guru j-QAF dan guru Pendidikan Islam, Pihak sekolah boleh melantik guru akademik yang berkebolehan al-Quran untuk dilibatkan dalam aktiviti tasmik sebagaimana yang telah digariskan di dalam buku panduan program j-QAF (Kementerian Pelajaran Malaysia 2008). Malah, pelajar yang telah khatam juga boleh dijadikan pelajar turus dan membantu guru untuk aktiviti tasmik.

Berdasarkan dapatan kajian ini, tahap pelaksanaan pengajaran Tilawah al-Quran program j-QAF adalah pada tahap yang tinggi iaitu dengan nilai min keseluruhan 4.24. Hasil dapatan juga menunjukkan tahap pelaksanaan pengajaran Asuhan Tilawah al-Quran mencapai tahap yang baik dan memuaskan. Pelaksanaan pengajaran Asuhan Tilawah al-Quran program jQAF melibatkan beberapa langkah yang meliputi set induksi, langkah satu, langkah dua, langkah tiga dan penilaian serta rumusan. Langkah-langkah ini adalah berdasarkan kepada pendekatan Ibnu Khaldun dalam model pengajaran al-Quran. Namun sebelum memulakan proses P\&P, guru perlu mengenalpasti tahap penguasaan bacaan al-Quran pelajar terlebih dahulu. Hasil dapatan menunjukkan majoriti di kalangan guru akan mengenalpasti tahap penguasaan pelajar terlebih dahulu sebelum memulakan pengajaran. Selain itu, hasil dapatan juga menunjukkan kebanyakan guru mengaitkan pengajaran dengan kehidupan pelajar seharian. Perkaitan ini memberi kefahaman yang lebih jelas dan dapat dipraktikkan dalam kehidupan seharian mereka. Dari segi kaedah pengajaran pula, talaqqi musyafahah tetap menjadi kaedah utama yang digunakan oleh guru dalam pengajaran Asuhan Tilawah al-Quran.

Apa yang paling penting dalam pengajaran Asuhan Tilawah al-Quran, hukum tajwid tidak ditekankan secara khusus. Ini adalah kerana tumpuan pengajaran Asuhan Tilawah alQuran dengan bacaan yang betul berdasarkan hukum tajwid (Kementerian Pelajaran Malaysia 2002). Dapatan kajian mendapati hampir keseluruhan responden yang menekankan bacaan al- 
Quran yang betul berdasarkan hukum tajwid secara khusus dalam pengajaran Asuhan Tilawah Al-Quran. Mohd Yusof Ahmad (2000) menyatakan kaedah talaqqi musyafahah merupakan faktor yang sangat penting agar pelajar benar-benar mengetahui secara amali bagaimana pelaksanaan semua hukum-hukum tajwid dalam bacaan yang terkandung makhraj-makhraj huruf, sifat-sifat huruf dan lain-lain hukum tajwid. Oleh kerana itu, guru perlu menguasai ilmu dan kemahiran bagi melahirkan pelajar yang mampu menguasai bacaan al-Quran dengan baik.

Penilaian pelaksanaan Kem Literasi al-Quran program j-QAF juga menunjukan dapatan tinggi dengan min keseluruhan 4.19. Dapatan menunjukkan hampir keseluruhan responden mengetahui dengan jelas matlamat Kem Literasi al-Quran. Penguasaan tentang matlamat Kem ini adalah perkara asas bagi seorang guru untuk meneliti, merancang dan melaksanakan sesuatu aktiviti yang mampu membimbing pelajar-pelajar yang tercicir agar dapat mencapai sekurang-kurangnya Iqra' 4. Pelajar boleh meneruskan bacaan sekiranya telah menguasainya. Daripada aspek pelaksanaan, terdapat di kalangan guru yang tidak melaksanakan Kem Literasi al-Quran pada waktu yang dicadangkan. Terdapat hasil mendapati seramai 60 orang responden yang kurang bersetuju, 6 orang responden tidak bersetuju dan 2 orang yang sangat tidak bersetuju.

Dapatan kajian juga mendapati ketidakmampuan pelajar menguasai bacaan Iqra' juga mungkin berkait rapat dengan cara pengajaran guru. Guru sewajarnya terlebih dahulu tahu kaedah untuk mengajar buku Iqra'. Sebagaimana dapatan kajian Mohd Alwi Yusof et al. (2003) menunjukkan hanya 35\% sahaja dalam kalangan guru yang menerima latihan dalam pengajaran kaedah Iqra'. Keadaan ini memberi kesan terhadap pengajaran guru seterusnya menyukarkan pelajar untuk mengusainya. Oleh kerana itu, pengajaran kaedah Iqra' perlu dipelajari bagi membolehkan guru melaksanakan pengajaran dengan cara yang betul dan tepat. Hasil dapatan menunjukkan keseluruhan item yang berkaitan dengan penilaian aspek proses mencapai tahap skor min yang tinggi. Ini menunjukkan guru-guru melaksanakan Kem Literasi al-Quran dari aspek proses sebagaimana yang dicadangkan. Namun bagi item yang mencapai skor min yang terendah ialah item "tidak menggunakan cara paksaan atau merotan supaya pelajar "membaca" dengan nilai $\min =4.03$. Ini menunjukkan terdapat guru yang bersetuju dan menggunakannya cara paksaan serta merotan untuk meminta pelajar membaca Iqra walaupun bilangannya kecil (15.4\%). Unsur-unsur paksaan dan kekasaran sewajarnya dielakkan kerana ia boleh mematahkan semangat dan motivasi pelajar untuk belajar al-Quran secara sukarela. Guru sewajarnya menjadi pembakar semangat kepada pelajar dalam melahirkan rasa kecintaan pelajar kepada minat membaca al-Quran.

Kajian ini juga mendapati hasil ujian korelasi Pearson, terdapat hubungan yang signifikan antara hubungan yang signifikan antara Model 6 Bulan Khatan al-Quran, Model Tasmik, Asuhan Tilawah al-Quran, Kem Literasi al-Quran dengan pengajaran Tilawah al-Quran j-QAF. Dapatan ini menunjukkan terdapat hubungan yang positif antara setiap model dan kejayaan setiap model ini mempunyai hubungan yang positif antara satu sama lain. Secara keseluruhannya, dapatlah dirumuskan bahawa guru-guru mempunyai penilaian yang positif terhadap pelaksanaan pengajaran model-model tilawah al-Quran program j-QAF iaitu Model 6 Bulan Khatan al-Quran, Model Tasmik, Asuhan Tilawah al-Quran, Kem Literasi al-Quran. Selain itu, berdasarkan penilaian guru-guru, terdapat hubungan yang kuat antara pelaksanan Model 6 Bulan Khatan al-Quran, Model Tasmik, Asuhan Tilawah al-Quran, Kem Literasi al-Quran dengan pengajaran Tilawah al-Quran j-QAF. Walaupun para responden bersetuju dan melaksanakan pengajaran tilawah al-Quran program j-QAF, namun masih terdapat beberapa aspek yang perlu diteliti dan dikaji semula tentang kerelevanan pelaksanaannya dan kelemahan yang perlu diatasi bagi meningkatkan keberkesanan program sedia ada ini. Antaranya ialah dari aspek matlamat pengajaran, strategi pengajaran, penambahan tenaga pengajar, kemudahan infrastruktur dan kursus peningkatan kemahiran guru. Pelaksanaan Program j-QAF khususnya dalam bidang tilawah al-Quran adalah langkah utama bagi memastikan pelajar-pelajar di peringkat sekolah rendah mampu menguasai bacaan al-Quran dengan baik. Pelbagai strategi, kaedah dan teknik yang boleh digunakan oleh guru-guru Pendidikan Islam/j-QAF bagi memastikan proses P\&P dapat dilaksanakan dengan berkesan dan mampu meresap ke dalam 
jiwa pelajar. Segala kemudahan yang telah disediakan hendaklah digunakan dengan baik dan berhemah. Oleh itu, sewajarnya guru-guru Pendidikan Islam/j-QAF dapat bersikap dan bertindak dengan lebih proaktif dan kreatif bagi merealisasikan hasrat KPM dalam melahirkan generasi celik al-Quran.

\section{References}

Azhar Ahmad. 2006. Strategi pembelajaran dan pengaturan kendiri pendidikan Islam dan penghayatan akhlak pelajar sekolah menengah. Tesis Doktor Falsafah, Universiti Kebangsaan Malaysia.

Kamarul Azmi Jasmi dan Ab. Halim Tamuri. 2012. Pendidikan Islam kaedah pengajaran dan pembelajaran. Skudai: Penerbit UTM.

Kementerian Pelajaran Malaysia. 2002. Sukatan pelajaran pendidikan Islam dan Moral. Kuala Lumpur Dewan Bahasa dan Pustaka.

Kementerian Pelajaran Malaysia. 2005. Buku panduan pelaksanaan model-model pengajaran dan pembelajaran dan ko-kurikulum tahun $2 \mathrm{~J}-Q A F$. Putrajaya: Bahagian Kurikulum Pendidikan Islam dan Moral, Jabatan Pendidikan Islam dan Moral, Kementerian Pelajaran Malaysia.

Kementerian Pelajaran Malaysia. 2008. Buku panduan pelaksanaan model-model pengajaran dan pembelajaran dan ko-kurikulum tahun 4 j-QAF. Putrajaya: Bahagian Kurikulum Pendidikan Islam dan Moral, Jabatan Pendidikan Islam dan Moral, Kementerian Pelajaran Malaysia.

Mohd Aderi Che Noh. 2004. Celik al-Quran di kalangan pelajar Tingkatan 1 di Zon Pudu Kuala Lumpur. Kertas projek penyelidikan, Fakulti Pendidikan, Universiti Kebangsaan Malaysia.

Mohd Aderi Che Noh \& Rohani Ahmad Tarmizi. 2009. Persepsi pelajar terhadap amalan pengajaran tilawah al-Quran. Jurnal Pendidikan Malaysia. Selangor: Universiti Kebangsaan Malaysia.

Mohd Alwi Yusoff, Adel M Abdulaziz \& Ahmad Kamel Mohamed. 2003. Keberkesanan Iqra' Sebagai Kaedah Pembelajaran. Negeri Sembilan: Kolej Universiti Islam Malaysia.

Mohd Azmir Mohd Nizah dan Mohd Azrani Asran. 2009. Isu dan cabaran j-QAF dalam memperkasakan pelajar Islam: kajian di Sekolah Kebangsaan Datuk Hj. Baginda, Melaka. Nilai: Universiti Sains Islam Malaysia.

Mohd Yusuf Ahmad. 2000. Sejarah dan kaedah pendidikan al-Quran. Kuala Lumpur: Universiti Malaya.

al-Na'miy, Abdullah Al-Amin. 1994. Kaedah dan teknik pengajaran menurut Ibn Khaldun dan alQabisi. Transl. Kuala Lumpur: Dewan Bahasa dan Pustaka.

Neuman, W.L. 2003. Social Research Methods: Qualitative and quantitative approaches. Needham Heights: Allyn and Bacon.

Norasmah Othman. 2002. Keberkesanan program keusahawanan remaja di sekolah menengah. Tesis Doktor Falsafah, Universiti Putra Malaysia.

Zaidi Razak, Noor Jamaliah Ibrahim, Mohd Yamani Idna Idris, Emran Mohd Tamil, Mohd Yakub @ Zulkifli Mohd Yusoff \& Noor Naemah Abdul Rahman. 2008. Quranic verse recitation recognition module for support in j-QAF learning: A review. IJCSNS International Journal of Computer Science and Network Security, 8(8): 207-216. 